\title{
Pemberdayaan Pemuda Melalui Pelatihan Penggunaan Media Sosial Untuk Peningkatan Pemasaran Produk Desa Semamung Kabupaten Sumbawa
}

\author{
Nurul Hudaningsih ${ }^{1}$ \\ Teknik Industri-Universitas Teknologi Sumbawa, nurul.hudaningsih@uts.ac.id \\ Miftahul Arzak ${ }^{2}$ \\ Ilmu Komunikasi-Universitas Teknologi Sumbawa,miftahul.arzak@uts.ac.id \\ Ryan Suarantalla ${ }^{3}$ \\ Teknik Industri-Universitas Teknologi Sumbawa, ryan.suarantalla@uts.ac.id
}

\begin{abstract}
Abstrak
Kebijakan pemerintah one village one product menjadi tantangan bagi masyarakat desa. Keberlanjutan produk tidak hanya dari keberadaanya namun ditentukan juga dari seberapa berjalan kemasifan pemasaran produk. Pemasaran dan kemasan merupakan hal yang penting dalam upaya menarik minat calon konsumen. Media sosial online saat ini menjadi media yang digunakan untuk melakukan promosi. Dengan adanya perkembangan IPTEK yang pesat, aktivitas komunikasi yang sifatnya konvensial perlahan-lahan menuju ke aktivitas komunikasi yang bersifat digital. Social Responsibility Community (SRC) Desa Semamung merupakan organisasi kepemudaan yang terletak di Desa Semamung. SRC memiliki potensi besar untuk dapat membantu pemasaran produk desa. Namun, terdapat kekurangan pengetahuan dan keterampilan para pemuda Desa Semamung dalam pemasaran online. Kegiatan Pengabdian kepada Masyarakat ini merupakan upaya mensinergiskan potensi anak muda di SRC Desa Semamung terhadap media sosial untuk pemasaran produk lokal Desa Semamung. Program dilakukan dengan pelatihan desain kemasan menggunakan Software Corel Draw, pelatihan promosi menggunakan media sosial (Facebook dan Instagram) yang efektif serta pendampingan. Kesimpulan program ini adalah upaya mensinergikan potensi pemuda dan kebutuhan pemasaran produk desa sangat efektif. Selanjutnya mitra (SRC Desa Semamung) tertarik untuk terus mengaplikasikan ilmu dan pengalaman yang didapat melalui program untuk keberlanjutan pemasaran produk Desa Semamung.
\end{abstract}

Kata Kunci : Pemberdayaan Pemuda Desa, Pemasaran, Produk Desa

\begin{abstract}
The government policy, one village, becomes a challenge for the village community. Product sustainability is not only based on its existence, but also determined by how massive the marketing of the product is. Marketing and packaging are important to attract the potential customers. Nowadays, social media is a medium to be used for promoting products. In regard to the rapid development of science and technology, conventional communication activities are slowly leading to the digital communication activities. Social Responsibility Community (SRC) of Semamung Village is a youth organization that is located in Semamung Village.
\end{abstract}


SRC has great potential to be able to improve the market village products. However, Semamung Village youth has still a lack of knowledge and skills in online marketing. This community service is an effort to synergize the potential of young people in SRC, Semamung Village, towards social media for marketing the local products of Semamung Village. The program is conducted by packaging design training using Corel Draw Software, promotion training using effective social media (Facebook and Instagram), and mentoring. The conclusion of this program is synergizing between the youth potential and the marketing needs. It is supposed to be an effectively way to improve the village products. Moreover, partners (SRC, Semamung Village) are interested in continuing to apply the knowledge and experience gained through the program for the marketing sustainability of Semamung Village products

Keywords : Empowerment of Village Youth, Marketing, Village Products

\section{Pendahuluan}

Globalisasi dan perdagangan bebas saat ini merupakan sebuah tantangan sekaligus peluang bagi pelaku bisnis di Indonesia. Peluang yang muncul adalah semakin meluasnya jaringan supply dan demand. Sedangakan menjadi sebuah tantangan bagi pelaku bisnis adalah persaingan bisnis yang semakin ketat. Untuk menumbuhkan minat konsumen dalam mencoba dan membeli sebuah produk diperlukan upaya dan berbagai strategi pemasaran yang efektif.

Media sosial online saat ini menjadi media baru yang banyak digunakan oleh para pemilik usaha untuk melakukan promosi ke masyarakat. Dengan adanya perkembangan IPTEK yang pesat, aktivitas komunikasi yang sifatnya konvensial perlahan-lahan menuju ke aktivitas komunikasi yang bersifat digital. Melalui media sosial, komunikasi tidak lagi terbatas pada ruang dan usia. Memasarkan bisnis melalui media sosial dapat membantu pelaku bisnis dalam memperluas merk, memperoleh visibilitas, dan membangun hubungan dengan pelanggan. Sedangkan menurut Jauhari (2010), tujuan dari penjualan dan pemasaran melalui duniaya maya memiliki banyak keuntungan, yaitu cakupan yang luas, tidak mengenal ruang dan waktu, dapat dilakukan kapan saja dan dimana saja.

Usaha kecil dan menengah (UKM) adalah salah satu bidang yang memberikan kontribusi yang signifikan dalam memacu pertumbuhan ekonomi Indonesia. Hal ini dikarenakan daya serap UKM terhadap tenaga kerja yang sangat besar dan dekat dengan rakyat kecil (Kuncoro, 2008). Menurut Supardi (2009), masalah utama yang dihadapi oleh UKM adalah pemasaran. Pemasaran dengan metode konvensional memerlukan biaya yang tinggi, misalnya saja membuka cabang baru, ikut pameran, pembuatan dan penyebaran brosur dan sebagainya. Berkembangnya internet menjadi sarana yang efisien untuk membuka jalur pemasaran model baru bagi produk UKM. Di samping biayanya relatif murah, dengan memanfaatkan internet penyebaran informasi akan lebih cepat dan jangkauannya lebih luas

Salah satu penyebab media sosial semakin marak digunakan adalah cakupannya yang luas. Indonesia merupakan salah satu negara di dunia dengan pengguna 
internet yang banyak. Menurut Data di Kementerian Informasi, 63 juta orang Indonesia merupakan pengguna internet. Sedangkan $95 \%$ merupakan pengguna media sosial. Arzak (2016) melakukan penelitian tentang penggunaan media sosial oleh komunitas anak muda yang berlokasi di Sumbawa. Menurut Arzak, dewasa ini semakin banyak komunitas anak muda yang menggunakan media sosial. Tujuan anak muda menggunakan media sosial selain untuk menunjukkan jati dirinya, media sosial juga digunakan sebagai media mempromosikan kegiatan-kegiatan mereka.

Menurut Jesse Drew bahwa anak muda lebih terampil atau familiar dibandingkan usia-usia di atas maupun di bawahnya dalam memanfaatkan teknologi, alasannya karena kegiatan-kegiatan yang mereka lakukan lebih dekat dengan teknologiteknologi yang sedang berkembang, seperti membuka web, mencari dan menshare musik, mencari literatur serta menemukan generasi-generasi sejenis dalam memanfaatkan medsos. Walaupun tidak dipungkiri sebagian kecil generasi di bawah maupun di atasnya juga ada yang mengkonsumsi medsos (Drew, 2013:8).

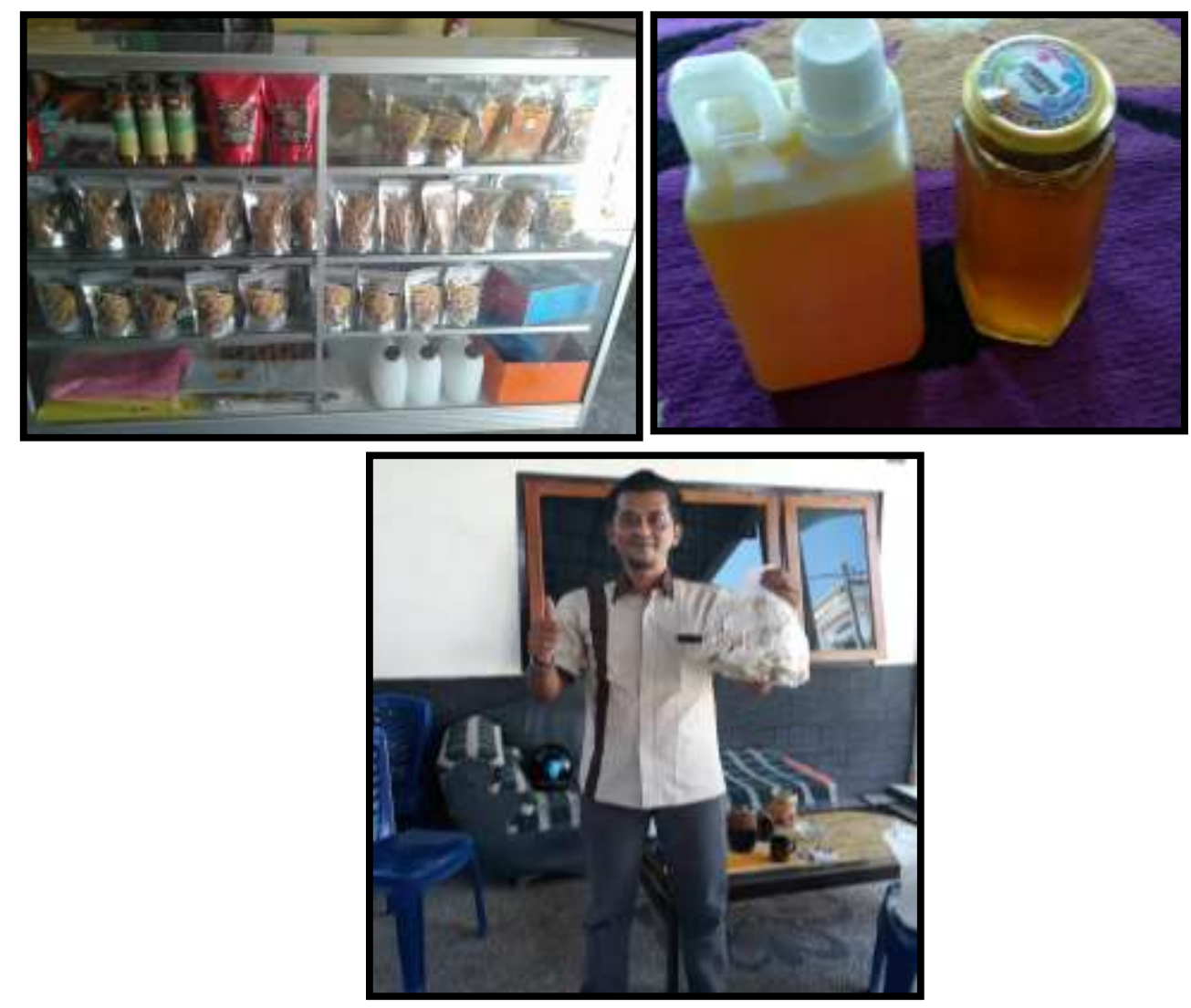

Gambar 1 (a) Olahan Jamur (b) Madu Hutan Sumbawa (c) Jamur Hasil Budidaya

Social Responsibility Community (SRC) Desa Semamung merupakan sebuah organisasi kepemudaan yang terletak di Desa Semamung, Kabupaten Sumbawa Besar. SRC Desa Semamung bertujuan untuk menjadi wadah dan sarana berpartisipasi serta berkontribusi para pemuda demi terwujudnya kemajuan Desa Semamung. 
Berdasarkan AD/ART SRC Desa Semamung, ruang lingkup kegiatan SRC Desa Semamung adalah mengadakan diskusi, seminar, pendidikan, pelatihan, penelitian, kegiatan sosial dan kajian-kajian lainnya. Selain itu, SRC Desa Semamung juga mengadakan komunikasi dan kerjasama yang proaktif (kemitraan) dengan Pemerintah, LSM, Ormas, Swasta dan pihak lain. Diharapkan melalui SRC Desa Semamung dapat membentuk pemuda-pemuda desa yang berakhlak, berkarya dan mandiri. Perkembangan kegiatan $S R C$ sampai saat ini tidak hanya berupa peningkatan kapasitas anggota saja, namun telah meningkat kepada kegiatan ekonomi yang melibatkan anggota-anggota SRC Desa Semamung. Kegiatan ekonomi yang dimaksudkan disini adalah kegiatan wirausaha untuk komoditi Madu Hutan Sumbawa, budidaya jamur serta produk olahan jamur.

Pada kegiatan ekonomi wirausaha yang disebutkan di atas, SRC Desa Semamung melibatkan seluruh anggotanya untuk mensupport keberlanjutan bisnis yang telah mereka laksanakan sejak tahun lalu. Kegiatan wirausaha meliputi kegiatan aktivitas mendapatkan bahan, mengolah bahan menjadi produk siap koonsumsi, packaging dan pemasaran. Saat ini cakupan penjualan meliputi Kabupaten Sumbawa Besar dan sekitarnya. Jumlah penjualan untuk Madu Hutan Sumbawa sekitar 10-20 kemasan/bulan. Jumlah penjualan jamur sebanyak 3-5 kg/minggu. Sedangkan jumlah penjualan produk olahan jamur mencapai $2 \mathrm{~kg} / \mathrm{minggu}$.

Pemasaran yang dilakukan oleh SRC Desa Semamung dilakukan secara offline maupun online. Untuk promosi secara online, SRC Desa Semamung menggunakan media sosial facebook. Dalam pelaksanaan pemasaran dan promosi online, masih dilakukan dengan sekedarnya tanpa perencanaan dan struktur yang rapi. Sedangkan untuk kemasan, SRC Desa Semamung menggunakan kemasan yang beragam. Ada kemasan produk yang menarik untuk produk olahan jamur namun hal tersebut tidak berlaku bagi produk jamur hasil budidaya yang dikemas dengan plastik seadanya. Pemasaran dan kemasan merupakan hal yang pennting dalam upaya menarik minat calon konsumen. Kedua hal tersebut adalah interface pertama yang dilihat oleh calon konsumen sebelum mereka menentukan membeli atau tidak sebuah produk.

Siswanto (2013) menyampaikan bahwa penggunan media social pada Usaha Kecil dan Menengah memberikan peningkatan daya saing bagi UKM. Dimana fungsi minimal media social bagi UKM setidaknya adalah menjalin komunikasi yang baik dengan konsumen ang telah ada dan menarik konsumen baru. Untuk mencapai fungsi tersebut UKM harus konsisten dalam melakukan komuikasi melalui media social, meningkatkan pemahaman dan kapasitas SDM dalam bidang IT termasuk di dalamna adalah penguasaan terhadap media social. Pamungkas (2016) melalui penelitiannya menunjukkan bahwa promosi melalui media social dan word of mouth secara simultan terhadap keputusan pembelian produk oleh konsumen. Promosi melalui media sosial dan WOM merupakan cara yang sangat efektif dan efisien dalam hal penyebaran informasi. Konsumen akan mengumpulkan berbagai informasi sebelum memutuskan membeli atau mengkonsumsi suatu produk. 
Melihat berbagai aspek diatas, perlu sekiranya upaya mensinergiskan potensi anak muda terhadap media sosial di SRC Desa Semamung tersebut terhadap pemasaran produk-produk lokal UKM atau produk-produk Desa Semamung. Namun, dibalik potensi besar yang ada, terdapat kekurangan pengetahuan dan keterampilan para anak muda Desa Semamung yang tergabung dalam SRC Desa Semamung. Oleh karena itu, perlu dilakukan sebuah usaha untuk menambah pengetahuan dan keterampilan para anak muda tersebut melalui Program Pengabdian kepada Msyarakat.

\section{Metode}

Untuk menyelesaikan permasalahan mitra berikut adalah penjelasan metodologi yang digunakan.

1. Workshop Desain Grafis

Kegiatan workshop desain grafis dilakukan dengan tujuan untuk melakukan transfer pengetahuan dan keterampilan dalam melakukan desain kemasan pada produk. Kegiatan workshop desain grafis dilakukan selama dua hari. Pelaksanaan Workshop dilakukan di Laboratorium Komputer Universitas Teknologi Sumbawa. Workshop dilaksanakan dengan target peserta minimal 9 orang.

Pada hari pertama, pada awal pelaksanaan workshop dilakukan FGD kepada seluruh peserta. FGD dilakukan untuk menggali pemahaman peserta terhadap konsep marketing serta mengetahui keterampilan mereka dalam menggunakan peralatan teknologi informasi (Komputer dan smartphone). Selanjutnya melalui workshop diperlihatkan contoh-contoh desain kemasan yang menarik bagi konsumen. Selanjutnya peserta diperkenalkan dengan software Corel Draw melalui komputer. Target pelaksaan workshop pada hari pertama adalah peserta memahami konten, manfaat dan urgensi kemasan produk yang menarik.

Pada hari kedua, workshop dilanjutkan melalui penggunaan software Corel Draw untuk desain-desain sederhana dan terus meningkat. Pada saat ini, peserta dibagi menjadi 3 kelompok dengan jumlah peserta minimal 3 orang per kelompok. Jumlah kelompok ini sesuai dengan jumlah produk yang saat ini dikeloloa oleh $S R C$ Desa Semamung. Hasil workshop berupa dokumen desain kemasan untuk produk-produk yang diproduksi oleh SRC Desa Semamung.

2. Workshop Penggunaan Media Sosial dan Bahasa Komunikasi dalam Promosi Produk

Kegiatan Workshop Penggunaan Media Sosial dan Bahasa Komunikasi dalam Promosi Produk dilaksankan selama 1 hari. Kegiatan ini dilakukan di Aula Desa Semamung dengan target jumlah peserta minimal sebanyak 6 orang. Workshop dimulai dengan melakukan penyampaian bahasa komunikasi dalam promosi produk yang tepat. Selanjutnya disampaikan terkait kiat dan strategi-strategi tentang meningkatkan pengikut/follower di media sosial (Facebook dan Instagram). Dilanjutkan dengan contoh penggunaan bahasa-bahasa promosi dalam media sosial tersebut. Hasil dari kegiatan ini adalah peserta dapat melakukan promosi 
yang efektif dengan menggunakan media sosial dibuktikan dengan meningkatnya jumlah pengikut pada media promosi produk SRC Desa Semamung.

\section{Pendampingan Peserta}

Kegiatan pendampingan peserta dilakukan dengan melakukan kunjungan ke seketariat SRC Desa Semamung. Kegiatan pendampingan ini dilakukan sebagai sarana follow up atas dua workshop yang telah dilakukan sebelumnya. Kegiatan pendampingan diisi dengan menanyakan permasalahan atas promosi media sosial yang telah mereka jalankan serta memberikan solusi atas permasalahan tersebut. Kegiatan pendampingan langsung dilakukan sebanyak dua kali sepanjang periode program pengabdian ini. Sedangkan untuk pendampingan lainnya kami lakukan melalui media sosial bersama.

\section{Hasil dan Pembahasan}

Hasil yang telah dicapai dalam pelaksanaan program Pengabdian kepada Masyarakat ini adalah :

1. Meningkatkan kesadaran dan pemahaman peserta bahwa anak muda harus terlibat aktif dalam pengembangan ekonomi Desa.

2. Meningkatnya keterampilan, pengetahuan dan pemahaman pemuda Desa Semamung tentang desain grafis kemasan produk . hal ini dapat digunakan oleh para pemuda Desa Semamung unuk melakukan perbaikan kemasan produkproduk desa ang mereka miliki.

3. Meningkatnya keterampilan, pengetahuan dan pemahaman pemuda Desa Semamung tentang penggunaan media social (Facebook dan Instagram) untuk melakukan pemasaran produk Desa Semamung. Hal ini membantu oleh para pemuda Desa Semamung unuk melakukan pemasaran dengan cakupan yang lebih luas namun dengan biaya yang murah. Hal ini tentunya akan meningkatan angka partisipasi Pemuda Desa Semamung untuk peningkatan kesejahteraan masyarakat Desa Semamung.

\section{Pelaksanaan Workshop Desain Grafis}

"Workshop Desain Grafis Kemasan Produk" telah dilaksanakan di Ruang Laboratorium Komputer Universitas Teknologi Sumbawa. Kegiatan ini merupakan hasil dari hibah Kemenristekdikti dari proposal yang telah diajukan oleh Nurul Hudaningsih, MT selaku ketua tim dan kedua rekannya yaitu Miftahul Arzak, S.Ikom., MA serta Ryan Suaratalla, S. Kom., MM. Proposal tersebut berjudul "Pemberdayaan Pemuda Desa dalam Peningkatan Produk Desa di Desa Semamung, Kabupaten Sumbawa".Selain 3 orang dosen UTS, kegiatan ini melibatkan 5 orang mahasiswa dari Prodi Ilmu Komunikasi dan Teknik Industri UTS.

Kegiatan ini berlangsung selama dua hari yakni pada tanggal 13-14 Juli 2019. Dimana pada hari pertama diisi oleh Nurul Hudaningsih, M.T., dengan materi Peran Pemuda dalam Peningkatan Ekonomi Desa. Selanjutnya materi disampaikan oleh Miftahul Arzak, S.Ikom., MA dengan materi Komunikasi Media Sosial. Pada hari kedua, pelatihan diisi dengan materi Desain Grafis oleh Aka Kurnia S.F, S.Ag., M.Sn. 
Peserta yang mengikuti workshop ini merupakan anggota dari Social Responsibility Community (SRC) Desa Semamung, BMT Insan Samawa, dan Pemuda Unter Iwes dengan usia rata-rata 17 sampai 23 tahun. Worksop ini diikuti oleh 21 orang. Melalui kegiatan ini Pemuda Desa mendapatkan ilmu mengenai Desain Grafis dan dapat diaplikasikan pada produk yang dihasilkan dan dapat dipasarkan melalui media sosial.

Melalui kegiatan workshop ini peserta mendapatkan pengetahuan sekaligus keterampilan baru tentang Desain Grafis Kemasan Produk. Melalui kuesioner online yang diisi oleh peserta pada saat awal workshop, diketahui bahwa $86 \%$ peserta tidak pernah membuat desain sebelumnya. Adapun 14\% lainnya merupakan pembuat desain yang masih baru. Dengan workshop ini, peserta merasa terbantu untuk mengenal dunia desain. Adapun hasil pengisian kuesioner sebelum dan sesudah (pre dan post test) secara detail disampaikan melalui table di bawah ini.

Tabel 1. Hasil Pre Test dan Post Test Workshop Desain Grafis.

\begin{tabular}{lll}
\hline No & Keterangan & Hasil Kuesioner \\
\hline 1 & Jumlah Responden & 19 orang \\
2 & $\begin{array}{l}\text { Peningkatan Pengetahuan } \\
\text { (pengecekan jawaban peserta workshop mengenai }\end{array}$ & $89 \%$ (17 orang) \\
& $\begin{array}{l}\text { materi workshop) } \\
\text { Peningkatan Keterampilan Desain } \\
\text { (pengecekan jawaban peserta workshop mengenai }\end{array}$ & $100 \%$ (19 orang) \\
& $\begin{array}{l}\text { langkah-langkah desain) } \\
4\end{array}$ & $\begin{array}{l}\text { Kebermanfaat Program } \\
\text { Memahami Urgensi Kemasan Produk }\end{array}$ \\
\hline
\end{tabular}

Berikut adalah dokumentasi Kegiatan Workshop Desain Grafis.
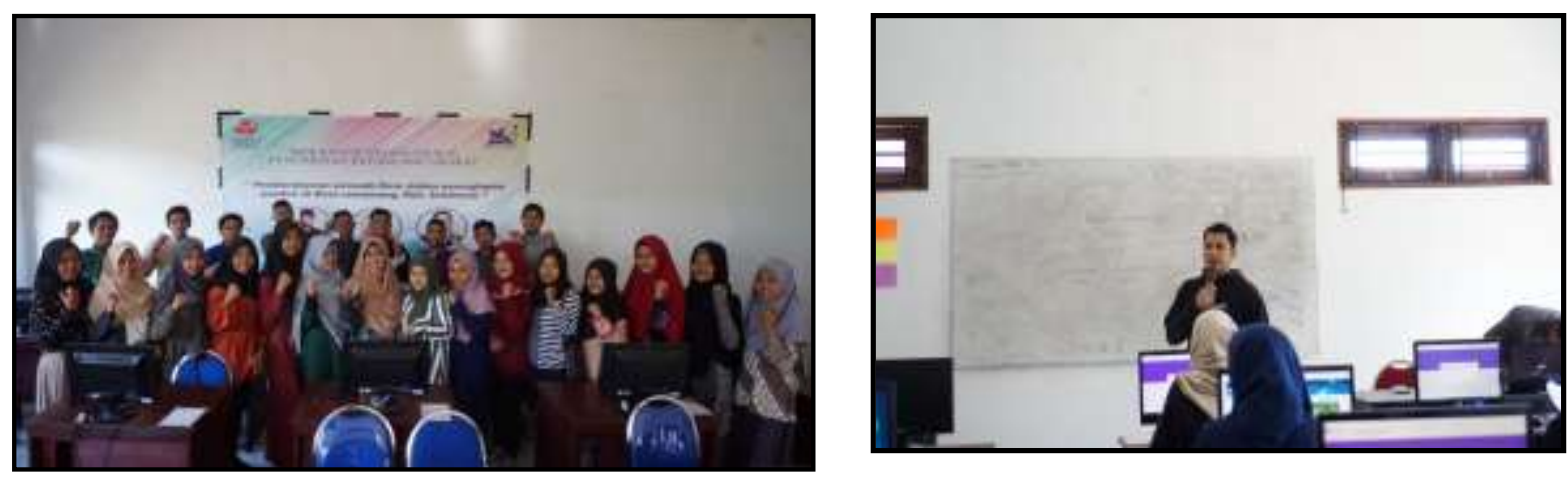

Gambar 2. Dokumentasi Workshop Desain Grafis Kemasan Produk

Pelaksanaan Workshop Optimalisasi Media Online untuk Pemasaran Produk Desa Minggu, 25 Agustus 2019 telah berlangsung kegiatan “Workshop Optimasi Media Sosial untuk Pemasaran Produk Desa" yang bertempat di Kantor Desa Semamung dan diikuti oleh anggota dari Social Responsibility Community(SRC) Desa 
Semamung dengan usia rata-rata 17 sampai 23 tahun. Kegiatan ini merupakan hasil dari hibah dana Kemenristekdikti dari proposal yang berjudul "Pemberdayaan Pemuda Desa dalam Peningkatan Produk Desa di Desa Semamung, Kabupaten Sumbawa. Proposal ini diajukan pada tahun 2018 oleh Nurul Hudaningsih ST., MT beserta kedua rekannya, Miftahul Arzak S.Ikom., MA dan Ryan Suarantalla S.Kom., MM. Selain 3 orang dosen UTS, kegiatan ini melibatkan 5 orang mahasiswa dari Prodi Ilmu Komunikasi dan Teknik Industri UTS.

Kegiatan ini merupakan kelanjutan dari "Workshop Desain Grafis Kemasan Produk" yang pernah dilaksanakan selama dua hari yaitu 13-14 Juli 2019 di Laboratorium Komputer Universitas Teknologi Sumbawa (UTS) dan diadakan pada 25 Agustus 2019 di Kantor Desa Semamung. Workshop ini sengaja dibuat secara bertahap, diharapkan agar pemahaman peserta bisa lebih maksimal. Pelaksanaan workshop berlangsung dari pukul 09.00 WITA hingga pukul 15.00 WITA dan diisi oleh tiga pemateri. Yaitu Nurul Hudaningsih, M.T dengan materi peluang Produk Desa, Ryan Suarantalla S.Kom., MM dengan materi Pemasaran dan I Made Widiarta S.Komp yang menyampaikan tentang Digital Marketing. Dalam kegiatan ini, para peserta difasilitasi dengan modul panduan yang dapat dimanfaatkan sebagai sumber referensi. Selain menerima materi secara teori, peserta juga diarahkan untuk mempraktekkan secara langsung bagaimana cara memaksimalkan media sosial sebagai sarana pemasaran. Kegiatan workshop diakhiri dengan sesi tanya jawab dan ucapan terimakasih dari Nurul Hudaningsih ST., MT selaku Ketua TIM PKMS.
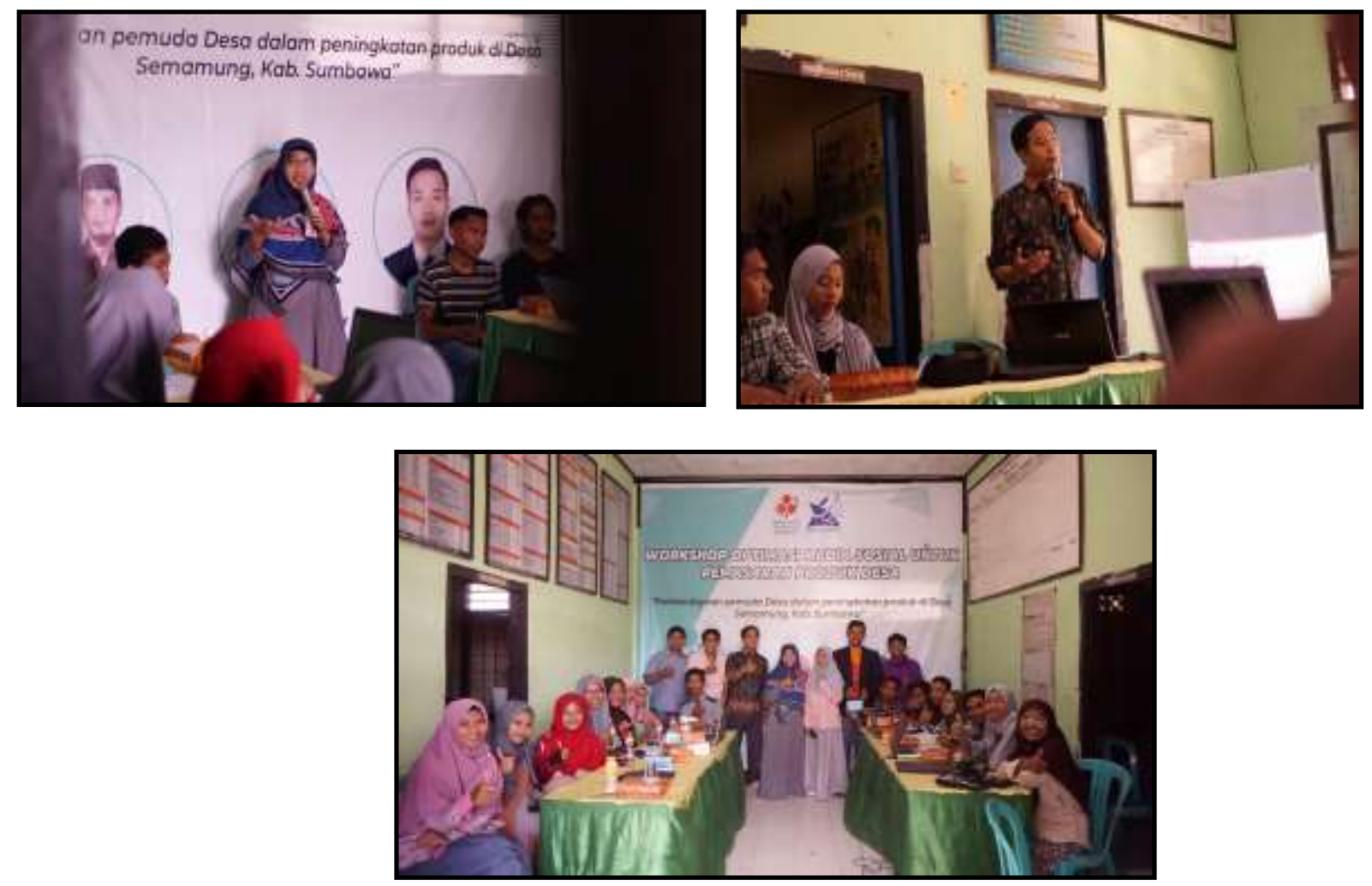

Gambar 3. Dokumentasi Workshop Desain Optimasi Media Sosial untuk Pemasaran Produk Desa 
Melalui workshop kedua ini, peserta mendapat pengetahuan baru mengenai media online (Facebook dan Instagram). Sebagian peserta (93\%) baru mengetahui fitur-fitur penunjang bisnis pada kedua media social tersebut. Sedangkan $86 \%$ dari peserta yang hadir merasakan adanya peningkatan keterampilan dalam menggunakan fiturfitur bisnis pada kedua media social tersebut. Adapun Hasil Pre Test dan Post Test Workshop Optimasi Media Sosial untuk Pemasaran dapat dilihat melalui tabel berikut ini.

Tabel 2. Hasil Pre Test dan Post Test Workshop Optimasi Media Sosial untuk Pemasaran

\begin{tabular}{lll}
\hline No & Keterangan & Hasil Kuesioner \\
\hline 1 & Jumlah Responden & 15 orang \\
2 & $\begin{array}{l}\text { Peningkatan Pengetahuan } \\
\text { (pengecekan jawaban peserta workshop mengenai }\end{array}$ & $93 \%$ (14 orang) \\
& $\begin{array}{l}\text { materi workshop) } \\
3\end{array}$ & $\begin{array}{l}\text { Peningkatan Keterampilan Penggunaan Media Sosial } \\
\text { (pengecekan jawaban peserta workshop mengenai }\end{array}$ \\
& $\begin{array}{l}\text { langkah-langkah membuat akun sosial media untuk } \\
\text { bisnis) }\end{array}$ & \\
4 & Kebermanfaat Program & $100 \%$ \\
\hline
\end{tabular}

\section{Pendampingan}

Pendampingan dilakukan untuk memberikan pengarahan kerja dan evaluasi bagi progress yang telah mitra laksanakan. Adapun target dalam pendampingan ini adalah :

1. Pembuatan fanpage dan akun Instagram BUMDES SEMAMUNG

2. Membuat Publikasi Produk pada fanpage yang telah dibuat

3. Daftar Susunan Konten publikasi produk

4. Asistensi desain kemasan produk desa.

Pendampingan mitra dilaksanakan pada 6-7 Desember 2019. Pendampingan dilaksanakan di 2 lokasi yaitu di Kantor Desa Semamung dan UTS. Melalui pendampingan, Tim PKMS memastikan bahwa mitra paham seluruh materi yang telah diberikan dan memahami langkah selanjutnya yang harus dilaksanakan

\section{Simpulan dan Rekomendasi}

Dari hasil kegiatan ini dapat disimpulkan bahwa program yang telah dilaksanakan dapat meningkatnya kemampuan, pengetahuan dan ketrampilan peserta dalam bidang pemasaran. Selain itu peserta dapat memahami dan menguasai keterampilan dalam medesain kemasan produk yang menarik melalui software coreldraw serta dapat memahami dan menguasai keterampilan dalam menggunakan media social (Facebook dan Instagram) sebagai sarana memasarkan produk-produk Desa Semamung. Hal ini dapat dilihat dari respon positif dari para peserta atas pelatihan yang telah dilakukan. Rencana tahapan berikutnya yaitu masih diperlukan 
pendampingan mengenai pendalaman dalam desain grafis serta komunikasi dengan para konsumen. Selain itu, diperlukan pula disampaikan tentang bagaimana melakukan manajemen hubungan dengan konsumen

\section{Daftar Pustaka}

Arzak, Miftahul. 2016. Jalan Menuju Surga (Anak Muda, Media Sosial dan Komunitas Sosial di Sumbawa). Jurnal Tambora Vol.1 No.2

Drew, Jesse. (2013). A Social History of Contemporary Democratic Media. Routledge: London.

Jauhari, Jaidan. 2010. Upaya Pengembangan Usaha Kecil dan Menegah (UKM) dengan Memanfaatkan E-Commerce. Jurnal Sistem Informasi (JSI). Vol.2 No.1

Kuncoro, Mudrajad, 2008. Tujuh Tantangan UKM di Tengah Krisis Global. Harian Bisnis Indonesia 21 Oktober 2008.

Pamungkas, Bagas Aji. 2016. Pengaruh Promosi di Media Sosial dan Word Of Mouth terhadap Keputusan Pembelian (Studi Kasus pada Kedai Bontacos, Jombang). Jurnal Komunikasi, Vol.X, No 2. 2016, halaman 145-160

Priambada, Swasta. 2015. Manfaat Penggunaan Media SosialPada Usaha Kecil dan Menengah. Prosiding Seminar Nasional sistem Informasi Indonesia Tahun 2015.

Siswanto, Tito. 2013. Optimalisasi Sosial Media Sebagai media Pemasaran Usaha kecil dan Menengah. Jurnal Liquidity, Vol. 2, No.1, hlm.80-86

Supardi, Julian. 2009. Rancang Bangun Collaborative System Pemasaran Hotel Secara on-line Dengan Pendekatan Mediator based. Jurnal Sistem Informasi Fasilkom Unsri Vol 1 No 2 